Modern Asian Studies 52, 3 (2018) pp. 917-941. (C) Cambridge University Press 2018 doi:10.1017/Soo26749X17000142

\title{
Torture and Laughter: Naxal insurgency, custodial violence, and inmate resistance in a women's correctional facility in I97os Calcutta
}

\author{
ATREYEE SEN
}

Department of Anthropology, University of Copenhagen

Email:Atreyee.Sen@anthro.ku.dk

\begin{abstract}
This article explores the politics of surveillance, suppression, and resistance within a women's correctional facility in 1970 S Calcutta, a city in eastern India. I highlight the excessively violent treatment of women political prisoners, who were captured and tortured for their active participation in a Maoist guerrilla (Naxal) movement. I argue that the state officials who formed the lowest rung of the government's machinery to supress the movement-the police, prison guards, and wardens-partially usurped these carceral worlds during conditions of social unrest to create small regimes of de facto sovereignty over prison publics. During that critical period in the history of political uprising in the region, the central government coercively implemented a series of 'constitutional actions' in the name of internal security threats and withdrew civil liberties from Indian citizens. Political opponents were captured and imprisoned, and prisons became a space for licensed excess. I show how women political prisoners cooperated and conspired with women convicts (the latter having nurtured their own coping skills and structures to deal with persecution and negligence while in the detention system) to develop multiple forms of resistance to the extra-legal use of authority in prison, especially in the context of a volatile socio-political environment in the city.
\end{abstract}

\section{Introduction}

When young girls in school and college have the education to touch and open difficult books by Mao or whomever they followed during the Naxal movement, then they should use those same hands to hold a serving spoon for their children at dinnertime. Say, they were not interested in being good wives and good mothers, then they could have done something for the country 
(desher jonno kichu korte parto), but they chose to hold a gun instead! They are privileged women. Poor women come to prison because they have stolen from someone, sold their bodies or murdered someone who abused them, their actions stem from poverty. And I will still punish poor women. Then why should I spare political women from punishment in prison? The Naxal guerrillas can think they are heroines, but in jail they are zero-ines. Once you are captured by the police, it's over (ekbaar pulisher hatey dhora porle, shob shesh).

-Shyamala (8o), personal interview, former prison warden, Calcutta, 2012.

The children of women convicts in prison, they cried all the time. We often stood at the end of our cells, our hands clasped around the iron bars, looking at them helplessly. We did not know how to comfort them. Some of them called out for their mothers, and the sound of their loud weeping would ring in our ears. My cellmates, who were also my one-time comrades in the movement, we decided to find a way to make the children happy. We collected whatever odd bits and bobs that we found abandoned in the cell or in the yard (buttons, sari borders, pieces of paper, needle and thread, shards of glass and pieces of wood), and at night, we would pile them up in the middle of the cell. For hours, we sat around these scraps wondering what we could do with them. Even if we made rag toys, we couldn't sneak it out of the cells. If we did, there wouldn't be enough toys for so many children. Then one day, we decided to make puppets out of them. We made crude dolls with our odd collection of things, I had never done anything like this before. We tore long strips out of our sari borders and made sturdy ropes to make the puppets dance. Whenever the guards were not looking, at times in the middle of the night, we would slip the dolls through the bars, make them wiggle about and sing funny songs. It made us laugh, it made the children giggle. One day a prison guard asked us, 'Why are those half-dead children chuckling (adh-mora gulo hasche keno)?' We were sitting on our puppets, we could barely move, but we said loudly: '(karon ora ekhono more ni) They are not dead yet.' It was our little triumph.

- Mita (65), personal interview, former female Naxal political prisoner, Calcutta, 201 2. ${ }^{1}$

This article will explore strategies of resistance and countersurveillance generated by a group of women political prisoners that challenged the legitimacy of state torture and corruption in a women's correctional facility in 1970 s Calcutta, the capital of West Bengal. It was a turbulent period in the history of the region, a time when, en masse, students joined an anti-state uprising called the Naxal movement. The latter used armed revolutionary tactics to oppose the state and the upper-caste, landed gentry, and developed de facto sovereign rule over parts of rural Bengal. ${ }^{2}$ The state government

${ }^{1}$ The names of my informants have been anonymized.

${ }^{2}$ S. Banerjee (2009), In the Wake of Naxalbari: Four Decades of a Simmering Revolution, Sahitya Samsad, Kolkata, pp. viii-xvi. 
retaliated with extreme police brutality-arresting, torturing, and executing large numbers of young people affiliated with the struggle. ${ }^{3}$ During that period, the central government instituted President's Rule (in West Bengal) and later declared the infamous Indian Emergency to protect internal security, which led to a further withdrawal of civil and political rights from Indian citizens. On the ground, unlimited powers offered to state officials were grossly misused, with local police forces aggressively hunting down antinational political activists. In this context, the prisons became spaces of licensed excess. In Calcutta, many prison and police officials collectively permitted themselves a violent variety of self-styled, de facto sovereignty in their dealing with political inmates (partly as revenge against the movement which unlawfully mimicked and undermined state authority). Illegal and invasive interrogation tactics led to the violent death and disappearance of Naxal activists and sympathizers captured in the city. ${ }^{4}$ The political elite and sections of the influential middle classes established and supported the public authority of the prison system in the context of this volatile political environment (which lasted for a decade). But the ferocious expression of this authority, often as daily kachua dholai of political prisoners (the infamous parrot perch, or beatings while hanging upside down), systematically eroded everyday civil and legal rights accessible to carceral publics.

In 2008-9, I documented the ethno-histories of a community of ageing political prisoners in Calcutta and studied how urban political histories can be mapped through its cultures of confinement. I collected and analysed the narratives of former political prisoners, their friends, families, supporters, sympathizers, neighbours, new networks, activists, and journalists from that time, and also those of peer and kin groups who had severed relationships with the insurgents. I undertook this study in order to comprehend the myriad ways in which the Naxal movement in the 1970s engendered and impacted on everyday understandings of custodial violence, state torture, and 'the political prison' in post-colonial urban India. For this article, my ethnography specifically relates the experiences of a group of former women insurgents imprisoned for several overlapping years

${ }^{3}$ P. N. Mukherjee (1978), 'Naxalbari Movement and the Peasant Revolt in North Bengal', in M. S. A. Rao (ed.), Social Movements in India, Manohar, New Delhi.

${ }^{4}$ A. K. Mukhopadhyay (2006), 'Through the Eyes of the Police: Naxalites in Calcutta in the 1970s', Economic and Political Weekly, vol. 41, no. 29, pp. 3227-3233. 
in Alipore Central Jail between 1969 and 1977 (after which Naxal political prisoners were granted amnesty in West Bengal). Most of these women, now sexa- and septuagenarians, were lower middleclass, middle- and upper-caste young women, who fled from families, extended kin, marriages, motherhood, and educational degrees to join the Naxal movement, both in the villages and in the cities. They were eventually captured by the police and served prison sentences (of between six months and nine years) at the women's correctional facility in Calcutta. This article shows how these Naxal women teamed up with ordinary convicts in these jails to develop informal survival and surveillance strategies (such as laughter and loud music to distract prison officials) that kept the illicit activities of the local police-the lowest rung of the state machinery-under limited inspection. Since this article is not borne out of 'see and hear' ethnography, I have juxtaposed fictional, historical, written, and oral narratives. Instead of emphasizing the role of accuracy and truth telling, I have tried to offer women's shared impressions of (what they described as) extraordinary and exceptional experiences in the ordinary and quotidian routines of prison life. It is the incomplete and fragmented nature of their accounts that weaves this article into a tapestry of human resilience.

The modern prison is represented within both democratic and autocratic regimes as a space for the exertion of sovereignty, where the legal power of prison agencies, managers, and officials to repress rebellious and dangerous populations is often unavailable for external scrutiny. ${ }^{5}$ In many colonized nations of the global South, traditional forms of punishment or 'the rule of man' stemmed from backward religious and community-based social authority, and 'the rule of law' developed by the state retained moral authority as a neutral, functioning ideology and successful political legitimizer. According to Ocko and Gilmartin, who studied the conceptual opposition between 'the rule of man' and 'the rule of law' as central to the definition of sovereignty in British India and Qing China, this dichotomy opened up an inescapable paradox. ${ }^{6}$ While it led to the justification of a legal elite in both colonial and post-colonial India, 'in practice, the rule of law could never, of course, be separated from the rule of man,

\footnotetext{
${ }^{5}$ A. Rao and S. Dube (eds) (2015), Crime Through Time, Oxford University Press, Oxford.

${ }^{6}$ J. K. Ocko and D. Gilmartin (2009), 'State, Sovereignty, and the People: A Comparison of the "Rule of Law" in China and India', The Journal of Asian Studies, vol. 68 , no. 1. pp. $55^{-100 .}$
} 
because without human administration the law means nothing'. ${ }^{7}$ This article shows how this tension between the ethical use of sovereign power and the everyday human administration of rational, legal authority makes the bureaucratic management of the prison systems in South Asia heavily multilayered, especially during conflict. Deviance and corruption within this system rely largely on the invisibility of prison life, especially when related to the question of housing captured political prisoners who have challenged the authority of the state. ${ }^{8}$ Public opinion on political imprisonment is usually created and mobilized around select issues of capital punishment, jailbreaks, and the arrest of influential figures within a region's diverse political landscape. However, the 'continuous state spectacle asserting and affirming the authority of the state ${ }^{9}$ remains insular and directed inwards towards prison publics, as the daily workings of these secret and cordoned off spaces, of state-sponsored containment, are rarely accountable to the ordinary, conformist citizenry.

According to Huhn, de facto sovereignty is often simply the achievement of the Kantian sublime, that is the staging of domination by state and non-state political players who use repetitive violence and counter-violence, which appear to be uninteresting and ordinary, but are elevated to the level of principle as they give the perpetrators a sense of concealed pleasure. ${ }^{10}$ For the purpose of this article, I focus on (a) the actors who govern prisons on a daily basis-prison wardens, officials-who are from lower-class, low-caste backgrounds and were given the responsibility to act on behalf of the state to rein in (b) upper- and middle-class/-caste guerrilla women captured during police raids. I focus attention on multiple practices of revenge, sovereignty, and resistance within this carceral universe, and also show how the limited exertion of authority by political prisoners and prison guards led to concealed joy, vindication, and satisfaction on both sides.

The article, however, puts forward two case studies which mainly highlight the limits of de facto sovereign practices generated by state players. I analyse the actions of women political prisoners who

\footnotetext{
${ }^{7}$ Ibid., p. 93 .

${ }^{8}$ T. Martin and A. Jefferson (eds) (2014), 'Editorial Comment: Everyday Prison Governance in Africa', Prison Service Journal, vol. 212 , pp. 2-10.

${ }^{9}$ T. Hansen and F. Stepputat (eds) (2001), States of Imagination: Ethnographic Explorations of the Postcolonial State, Duke University Press, Durham, NC, p. 27.

${ }^{10}$ T. Huhn (1995), 'The Kantian Sublime and the Nostalgia for Violence', The Journal of Aesthetics and Art Criticism, vol. 53, no. 3, pp. 269-275.
} 
collaborated with women convicts and criminals, and used gendered cultural repertoires within their disciplinary orbit to resist excessive state authority. I underline how indiscipline and mockery of the state formed a vital resource to momentarily weaken state power, even in the context of mass incarceration during a critical phase in the history of state brutality in India. In the course of the political uprising, Naxal women used high ideology, guerrilla warfare, and limited weaponry to exercise de facto sovereignty in regions captured by their comrades. When captured themselves, they used conventional cultural resources as 'craft' ${ }^{11}$ to evade a strict detention system. Even though the women represented their prison experiences as a clash between public authority (sarkari kotritya) and people's authority (janatar odhikaar), this article highlights the ways in which these boundaries were made malleable, while political prisoners, wardens, policemen, and convicts shared and negotiated the confines of prison life. Most of the voices in this article (whether in the form of interviews or prison memoirs) belong to former women political prisoners.

\section{Cruelty and compassion: wardens, prison kingdoms, and the torture of Naxal women}

The term 'Naxal' derives from a village named Naxalbari in West Bengal, a federal state in western India, where a radical movement inspired by Maoist political ideology was born. ${ }^{12}$ The movement was led by Charu Majumdar, Kanu Sanyal, and Jangal Santhal who initiated a violent anti-state uprising in the village in 1967 . The movement's powerful leadership advocated that Indian peasants and tribals use armed revolution to overthrow the government and upperclass landlords, and redistribute land to the tenants and the landless. As the popularity of the movement spread throughout the region, a large number of urban elites became attracted to its romantic, anti-feudalistic ideology. ${ }^{13}$ In the 1970 s, during a prolonged period of recession and industrial unemployment, the Naxalites also gained

${ }^{11}$ Bert Suykens and Bart Klem, 'The Politics of Order and Disturbance: Public Authority, Sovereignty, and Violent Contestation in South Asia' in this special issue.

${ }^{12}$ S. Ghosh (2009), Naxalbari Before and After, New Age Publications, New Delhi.

${ }^{13}$ H. Donner (2004), 'The Significance of Naxalbari: Accounts of Personal Involvement and Politics in West Bengal', Occasional Papers 14, Centre of South Asian Studies, University of Cambridge, Cambridge. 
prominence among sections of the student population in Calcutta, the capital of West Bengal. To mobilize more urban youth, Majumdar declared that revolutionary warfare could also take place in the cities and that this insurrectionary climate would bridge the gap between rural and urban workers. His 'annihilation line' clearly encouraged Naxal comrades to assassinate individual 'class enemies', resulting in the murders of a number of landlords, 'comprador' businessmen, police officers, and politicians in the city. ${ }^{14}$ The Naxals also systematically targeted unsympathetic civilians who were considered to be the movement's 'traitors', as well as police informants who were identified as 'spies'. In this volatile socio-political context, students left schools and colleges to join the violent movement and the Naxals eventually gained control of university and college facilities, not only in Calcutta but also in Delhi. ${ }^{15}$

The ruling Congress Party in West Bengal instituted strong countermeasures against the Naxalites. ${ }^{16}$ The judiciary justified all forms of extra-legal police brutality and the unregulated killing of Naxalites to contest political opposition. ${ }^{17}$ Through sustained torture and the systematic execution of young men, described in contemporary studies of conflict as state 'gendercide', ${ }^{18}$ the post-colonial democratic state represented itself as a new avatar of colonialist repression and dissolved the idealistic imaginings of political imprisonment that was popularized during the anti-colonial struggle in Bengal. ${ }^{19}$ When the prisons were full, even the homes of local Congress and soft Left politicians were turned into informal torture chambers by the police and the Congress Party cadres. Individual policemen began to settle old scores with non-political youth groups by falsely accusing them of promoting Naxal ideologies. This form of state terror became a source of distress within the popular imagination, even among those communities and neighbourhoods in Calcutta that were

${ }^{14}$ R. Ray (1988), The Naxalites and Their Ideology, Oxford University Press, Delhi.

${ }^{15}$ P. Basu (2000), Towards Naxalbari (1953-1967): An Account of Inner-party Ideological Struggle, Progressive Publishers, Calcutta.

${ }^{16}$ B. Dasgupta (1974), The Naxalite Movement, Allied Publishers, New Delhi.

${ }^{17}$ S. Jawaid (1979), The Naxalite Movement in India: Origin and Failure of the Maoist Revolutionary Strategy in West Bengal, 1967-1971, Associated Publishing House, Delhi.

${ }^{18}$ M. Mamdani (2001), When Victims Become Killers: Colonialism, Nativism and the Genocide in Rwanda, Princeton University Press, Princeton, NJ.

${ }^{19}$ D. Arnold (2004), 'The Self and the Cell: Indian Prison Narratives as Life Histories', in D. Arnold and S. Blackburn (eds), Telling Lives in India: Biography, Autobiography, and Life History, Indiana University Press, Bloomington, pp. 29-53. 
initially against the violent actions of the Naxalites. ${ }^{20}$ After suffering a number of political losses, the Naxalites eventually alleged human rights violations and accused the West Bengal police of vigorous persecution. In his research, Mukhopadhyay, while sieving through police records written by senior intelligence officers during the peak of the movement in Calcutta, discovered that the government responded to these accusations by arguing that effectively they were fighting assassins, which led to the death of unarmed civilians and ordinary policemen. ${ }^{21}$

Scholars such as Srila Roy ${ }^{22}$ and Mallarika Sinha Roy ${ }^{23}$ highlight the significant political role played by Naxal women in the 1970s. Through the paradigm of 'cultural memory', they explore the disenchantment of radical women who failed to secure their full participation in the movement led by the Communist Party of India (MarxistLeninist) with its supposedly liberatory agenda. Sinha Roy argues further that women's history related to Left radical movements focuses on the recovery of narratives of 'loss and pain', and the latter has a propensity to slip into a quagmire of the 'politics of blame'. She shows how the portrayal of women participants in these radical movements as suffering victims or as agents displaying 'astounding heroism' in periods of crisis fail to underline the complexities of women's political agency, and offer two polar opposite images of women revolutionaries. ${ }^{24}$ The prison narratives I recovered, contribute substantially towards developing knotty and convoluted understandings of Naxal women's agency. Their shared narratives illustrate how they moved deftly and defiantly between discourses of agency and victimhood, authority and marginalization, freedom and submission, joy and sadness, expression and silence, while negotiating the unknown terrains of state-led interrogation and prolonged incarceration.

${ }^{20}$ H. Donner (2009), 'Radical Masculinity: Morality, Sociality and Relationships Through Recollections of Naxalite Activists', Dialectal Anthropology, vol. 33, no. 3/4, pp. $327-343$.

${ }^{21}$ A. K. Mukhopadhyay (ed.) (2006), The Naxalites: Through the Eyes of the Police. Select Notifications from the Calcutta Police Gazette. 1967-1975, Dey's Publishing, Kolkata.

${ }^{22}$ S. Roy (2012), Remembering Revolution: Gender, Violence, and Subjectivity in India's Naxalbari Movement, Oxford University Press, Delhi.

${ }^{23}$ M. Roy (2010), Gender and Radical Politics in India: Magic Moments of Naxalbari (1967-1975), Routledge, Abingdon, Oxon.

${ }^{24}$ M. Roy (2006), 'Speaking Silence: Narrative of Gender in the Historiography of the Naxalbari Movement in West Bengal (1967-75)', Journal of South Asian Development, vol. 1, no. 2, p. 223. 
Most of the women I met in the course of my research joined the struggle from urban/peri-urban regions. They were largely educated and from relatively conservative, Hindu, lower middle-class, middleand upper-caste family backgrounds. My research shows that urban Naxal women joined the movement for political reasons (such as ideological indoctrination, pressure, and persuasion from male members of their families as well as the allure of a revolution) and personal reasons (such as hoping to escape a future which involved marriage, family, children, small-time jobs for women, and also precluded the possibility of political passion, leadership roles, freedom to love outside the norms of traditional partnerships, and so on).

According to Roy, however, there was a sweeping gender-blindness in Naxalite political ideology. ${ }^{25}$ Most Naxal women across rural-urban divides eventually became cynical about the movement in the face of its discriminatory practices. Sinha Roy illustrates how significant women leaders of the movement found relief in being blacklisted by the police. Since their comrades did not recognize them as important contributors to the movement, at least the police represented them as formidable enemies. ${ }^{26}$ In my interview with Kalyani, a former revolutionary, she reminisced at length about the number of photos she took in various poses, so that 'her best face' would be published in the press should she be captured or executed. She admitted, though, that even though she had imagined herself as a glamorous yet commonplace political prisoner, she was not prepared for the torture and interrogation tactics designed by prison officials. Once captured and subjected to carceral power for the first time, Naxal women became deeply disillusioned with a prison system that was legally unequipped to deal with 'the woman revolutionary'.

According to several women political prisoners, a significant expression of de facto jurisdiction within the prison system lay in wardens, constables, and police officials who repeatedly reminded the inmates that 'ekhane amader rajotto, this place is our kingdom'. The women guerrillas were warned that once they fell into the hands of the prison officials, their class, caste, gender, and political status would not afford them any privilege. 'Ekhane tomader kono bonduk nei, you don't have your guns here,' a prison guard told a political prisoner, suggesting that a gun was a mere metaphor for multiple status-related freedoms.

\footnotetext{
${ }^{25}$ Roy, Remembering Revolution.

${ }^{26}$ Roy, 'Speaking Silence', p. 223.
} 
Women political prisoners were brutally beaten, sexually assaulted, and insulted by both male and female prison guards under the guise of 'interrogation', primarily to procure undisclosed information about the underground guerrilla movement.

Most political prisoners were ill-treated in (what the women described as) 'regular' ways: they were deprived of food, water, sanitation, and visitation and toilet privileges; given excreta in their food, dead fish in their milk, and subjected to unexpected and sudden slaps. In addition, some women Naxals in Calcutta were severely and spectacularly beaten, at times on their breasts with cricket bats to create 'a male chest' since politically active men were accepted more comfortably within Bengali patriarchal societies. Some of the women eventually had their chests cracked open, and through a weak lens of semi-consciousness, they watched while the female wardens dipped their feet in blood pouring out onto the prison floor, and joyfully danced around the room singing 'ami alta porechi, I have adorned my feet with rose red dye,' usually worn by married women in Bengal to mark an auspicious occasion.

Marnia Lazreg, while exploring the intimate relationship between the torture of women and colonial domination, argues that this variety of gendered, routine, and accepted torture is usually related to the 'otherness' of those subjected to it. Hence there is often less taboo in humiliating gun-toting women who are part of anti-state resistance movements, partly because criminalizing and punishing deviant women is common practice in most patriarchal cultures, and is legitimized and extended dramatically in prison. ${ }^{27} \mathrm{I}$ had the opportunity to speak to Shyamala, a low-caste, former female warden of the Alipore Central Jail; for her, the actions of the women guerrillas-leaving their privileged lives and even their children to take part in anti-state activities-did not attract her sympathy. For her, upper-class, upper- and middle-caste women who had the education to even comprehend the complex words of Mao and the power and opportunity to lead straightforward lives as mothers, wives, and workers, should have valued their advantages. Poor, lower-caste, and illiterate women who often did not have the freedom to lead ethical lives were violently reprimanded by the state for illegal activities that resulted from their desperation. Shyamala contended that the women guards and wardens, who were mostly from lower-caste backgrounds

${ }^{27}$ M. Lazreg (2008), Torture and the Twilight of Empire: From Algiers to Baghdad, Princeton University Press, Princeton, NJ. 
in poorly paid public employment, were not 'bad people' if they took some pleasure in dancing around after they had subdued insubordinate female guerrillas: 'Tate khoti ki, what is there to lose?' she asked.

Even though most of my interlocutors were critical of women wardens and women prison officials, women political prisoners have often retrospectively shown sympathy for prison wardens trapped in similar cycles of poverty, gender discrimination, and marginalization within the prison system. For example, Mary Tyler, in her prison memoirs, shows that women matines (female prisoners promoted to a supervisory post) and prison wardresses did not have any 'real' authority and were equally exploited within the prison system. ${ }^{28}$ Tyler, the wife of Naxal revolutionary Amalendu Sen, was imprisoned for five years in a prison in Bihar (on a range of illegal charges). During that period Tyler and her comrade, Kalpana, did not report the petty thefts and nastiness of the matines. Criticizing the divisive relationships between the convicts and the political prisoners, she asked: 'Why pick quarrels with the small fish when the sharks are waiting to devour you all?"29 She illustrated the various ways in which the wardresses were also 'locked in' with prisoners in the female ward, and they were not allowed to leave until the male warder opened a gate from outside. Tyler shows further that the female wardens who were abusive and unpleasant were also poor and their living conditions were deficient. According to Shyamala, during the peak of the movement she rarely got a day off and could not even get permission to buy rice and lentils to feed her children. Her family lived in a dilapidated, governmentowned lower income group apartment (where we met), and she was not home often enough to light lanterns for her children during the long power cuts. She was bullied by jail officers, taunted as weak and useless, especially if she did not manage to control the daily prison population (which remained agitated after being persistently goaded by vocal political prisoners). 'There were days I was so tired that I beat the girls even more. If they would just give me a few names then I could go home. There were days when my children went to bed hungry because I didn't return home in time to cook for them,' she said. Tyler declared that some of the women wardens she encountered were not entirely unkind, felt sad to keep female prisoners locked up all day, and some of them were bold enough to unlock the cells and let the

${ }^{28}$ M. Tyler (1977), My Years in an Indian Prison, Littlehampton Book Services Ltd., West Sussex.

${ }^{29}$ Ibid., p. 171 . 
inmates chat for an hour. However, my interviews with Shyamala and some of the Naxal women who were under her supervision showed that the wardens often displayed kindness as a form of (maternal) authority, to infantalize the prisoners and keep them anxious about the withdrawal of leniency.

Tyler reminds her readers that women wardens lived under the constant threat of arbitrary suspension. One woman was suspended because she allowed a prisoner's child to give flowers to Tyler. She also came to know, through the prisoners' network, that the wardresses lived in ramshackle government housing estates. She said: 'The conditions in their own living quarters were, if anything, even worse than inside the prison itself. Each family's accommodation consisted of a small low room and a tiny veranda and courtyard. Up to eight or nine people might be living in this confined space. ${ }^{30}$ The wardens often preferred to be on duty rather than in their small, dark quarters 'teeming with flies and mosquitoes and stinking from the open gutter that ran along the alley courtyard'. ${ }^{31}$ The women wardens were also subjected to sexual harassment from male police officers. Tyler tells the story of a warden who fell asleep on night duty and the chief head warden intervened to save her from a possible suspension. He later demanded sexual favours as 'payment'. When she refused, he constantly threatened her with dismissal. ${ }^{32}$

Shyamala said she would also look the other way when male warders interrogated and humiliated women political prisoners, since this would distract them from harassing and extracting money from the women wardens. 'Sometimes I did feel guilty if the girls had gotten a good beating, so I didn't intervene if other convicts were looking after them. At other times I was so frustrated with their stupid silence. I spent so many tiring hours in prison, all because a few books written by a load of foreigners had turned the heads of young Bengali girls [thoo, she spits on the ground]. I admit that I was happy that these Naxal women got a dholai,' she said. Steven Caton's research on ordinary ethics is important in comprehending Shyamala's logic. The author highlights the complexity of good and evil within the moral economy of Abu Ghraib and how ordinary players become implicated in diabolical prison abuses. Caton argues that people involved in the prison system, whether they are inmates or administrators, are not 'cogs in the

\footnotetext{
${ }^{30}$ Ibid., p. 200.

${ }^{31}$ Ibid., p. 201.

${ }^{32}$ Ibid., p. 202.
} 
machine'. ${ }^{33}$ Their actions, as in the case of prison wardens managing women political prisoners for the first time, are guided by intention, personal justification, and political legitimation.

For the women Naxalites I encountered in the course of this research, the face of the prison authority, as an effective offshoot of the idea of the state, was significantly male (purush shashito). Whether the prison wardens were male or female, going through phases of being tough or tolerant, the overall act of repression against poor or politically resistant citizens did not garner gendered sympathies. 'We wouldn't call them un-human (onamush), women wardens who watched other women being beaten and tortured had all become like men,' said Mita, a former Naxal political prisoner. This identification of prison authority as male is reinforced in Begona Aretxaga's identification of strip-searching women political prisoners in Northern Ireland as a violent technology of control. ${ }^{34}$ She shows how the prison constitutes a phantasmatic scenario of sexual violence, in which both the political and gender identities of prisoners are reinscribed with the power of a 'sovereign-acting' male body politic. Using the voices of a number of women political prisoners who were mass strip-searched by both women and men wardens (in 1992), she shows how wearing a common uniform-the riot dress-had the effect of blurring gender lines. ${ }^{35}$ Men and women officers appeared indistinguishable from afar, thus creating the impression that all of them could be men, adding a particular edge to the fear of violence. ${ }^{36}$ 'Indeed, that the technologies themselves might constitute a fantasy screen of detached objectivity in the management of bodies that masks a desire for total control, a jouissance that wildly exceeds the calculated rationality of punishment. After all, the technologies of the body used in prison bring into intimate contact warders and prisoners, those who punish and those punished, an intimate contact arising indeed out of a body field,' she argues. ${ }^{37}$ Foucault, while discussing the history of punishment, states: 'The training of behavior by a full time-table, the acquisition of habits, the constraints of the body, imply a very special relation between the

${ }^{33}$ S. Caton (2010), 'Abu Ghraib and the Problem of Evil', in M. Lambek (ed.), Ordinary Ethics: Anthropology, Language, and Action, Fordham University Press, Bronx, NY, p. 166.

${ }^{34}$ B. Aretxaga (2001), 'The Sexual Games of the Body Politic: Fantasy and State Violence in Northern Ireland', Culture, Medicine and Psychiatry, vol. 25, no. 1, pp. 1-27.

${ }^{35}$ Ibid., p. 10.

${ }^{36}$ Ibid., p. 13 .

${ }^{37}$ Ibid., p. 6. 
individual who is punished and the individual who punishes him. It is a relation that not only renders the dimension of the [public] spectacle useless; it excludes it. The agent of punishment must exercise total power, which no third party can disturb; the individual to be corrected must be entirely enveloped in the power that is being exercised over him. ${ }^{38}$ Aretxaga notes that this threat from within, this fantasy and intimacy of total control over others, through an arbitrary exchange of cruelty and compassion (as described by both the Naxal women and the wardens), is not just an ironic effect or a tactical miscalculation, but an intrinsic part of the functioning of the prison as a sovereign space. $^{39}$

\section{Love and laughter: women inmates and the interior life of a post-colonial prison}

Between 1970 and 1977 , there was an influx of women political prisoners, whether active members or aides of the Naxal movement, into jails. This had an impact on the internal dynamics of prison life in Calcutta's Alipore Central Jail, the main penal institution built during British rule in Bengal. The prison governing body was unprepared to cope with the expanding female inmate population and was unable to arrange separate living arrangements for political prisoners and ordinary women criminals. Many Naxal women were clustered together in small cells and treated with particular disdain because of their political activity. According to the former political prisoners, there were usually eight to ten warders, guards, and prison officials on 'normal days'. But there were increased number of policemen (and beatings) when the Naxals had scored 'a success' in the movement and the police needed more information on hideouts, supporters, leaders, and cadres. There were few human rights groups or prison reform organizations active in Calcutta at that time and hardly any individuals and institutions played an interventionist role in the lives of incarcerated women.

The convict women, some of whom were serving life sentences, had developed their own internal nexus for collectively coping with the harshness of prison life. These criminalized women and their children,

\footnotetext{
${ }^{38}$ M. Foucault (1979), Discipline and Punish: The Birth of the Prison, Vintage Books, New York, p. 129.

${ }^{39}$ Aretxaga, 'The Sexual Games of the Body Politic', p. 4.
} 
herded together in prison, also suffered endless abuse. In her prison memoirs, Joya Mitra, once a young student Naxalite imprisoned in a number of urban and district jails between 1970 and 1974, brings the reader repeatedly to the story of Shanta. The latter was serving several years in prison for stabbing her husband, who regularly thrashed her and their two children while in a drunken stupor. In her cell, Shanta's precious possession was a nail trimmer with which she carefully clipped her children's nails to keep them clean. However, when she refused to hand over the trimmer to the jail warden (who was keen to acquire it) she was accused of owning a dangerous weapon. She was stripped, shackled, and beaten as internal (and informal) punishment for her deviant behaviour. ${ }^{40}$

Several of my informants stated that poor, low-caste convicts were initially hostile to the presence of Naxal women as they suspected that the latter would get privileged treatment as educated and/or upperclass members of society. Ironically, it was the use of excessive force on the Naxalites, as well as growing awareness among inmates that the political cadres had struggled for the rights of the poor, that helped build a fragile camaraderie between the incarcerated women. Based on this bonhomie and mobilizing different levels of expertise, clusters of women prisoners designed multiple strategies to ward off the repressive tactics used by prison officials to sustain an authoritarian regime. At times they succeeded and at others, they failed. The following paragraphs will discuss two select examples of carefully coordinated performances in prison, which powerfully feminized a contested patriarchal space. These narratives were especially relevant for female political prisoners, as sexual trafficking of women and 'playing families' remained peculiar to women's correctional facilities.

Several of my women informants remembered their fear of both convict and political women 'vanishing' during the night. Criminalized women, especially those abandoned by their families, were trafficked into prostitution rackets in exchange for large sums of money or sent off to the homes/private parties of unethical police officers as sex slaves. Naxal women also went missing (usually presumed killed) after night-time interrogation by officials, and rumours were rife about rising body counts in the prison hospital mortuary. In addition to the abuse and beatings, these sudden disappearances were also used as a threat by prison guards to rein in deviant behaviour by women inmates.

\footnotetext{
${ }^{40}$ J. Mitra (2004), Killing Days: Prison Memoirs, Kali for Women, Delhi.
} 
'Do you also want to see the inside of a morgue?' a prison guard asked Mita when she wondered about the absence of an inmate who was not scheduled for release. Since the guards openly doctored jail records to cover up the rate of disappearances, the convicts, in collaboration with political prisoners, declared it necessary to patrol illegal activities by prison security. Sushmita (54), once a young Naxalite held as an undertrial in Alipore Central Jail (when she shared a cell with Mita), said:

We would often wake up in the middle of the night and hear an inmate screaming while she was being dragged away by the guards. Our doors were locked and there was little we could do to stop them. Mansa, an older prisoner, told me: 'This is going on for so long. You have to wait till you get older and the officers lose interest in ravaging your body. But this is the only space where they can find so many young women with no male guardians. So sex is for free. If they go to a brothel they will have to pay.' So we had to find a way of remaining within the cells but still ensuring that the prison officials were aware that we were watching and waiting for missing women to be returned to their cells. Forget our dignity, we just wanted our lives to be saved.

Through encouraging each other to confront the problem of missing women, the inmates came up with a number of ploys. By singing songs throughout the night, loudly playing music with pots and pans, banging together plates and mugs in their cells, by sharing life stories, cracking jokes and laughing loudly across individual lock-ups, the prisoners stayed awake through the night whenever an inmate was escorted off the premises. "If the guards came for a woman, her cell mates would reassure her and say "we will be awake till you come back". And then they would start singing, wake up the rest of the prisoners, and spread the news that a girl was gone,' said Sushmita. This sent out a warning signal to the guards that the latter were also under surveillance. If inmates were eventually brought back to their cells, they were cared for and bathed by their cellmates, clearly indicating to the officials that the women were not divided by apathy but deeply connected through co-dependent relationships. At times, while tending to battered political prisoners, the convicts sang inspirational songs equating the Maoist women with martial goddesses, and when a woman prisoner died of disease, starvation, or torture, the Naxal women sang anti-state political songs. Slogans with clapping such as 'pulish maro, astro karo, beat the police, snatch their weapons' and songs accompanied by drumming on utensils such as 'tomar bhason, tomar shashon, manbona, shunbona, your dictates, your authority, we will not obey, we will not pay heed' were learned, shared, and celebrated by convict women. According to my interviewees, the songs, slogans, and drumming on utensils built up 
notions of people's rights and authority (jonotar odhikar) to fight against public authority (shorkari korityo). In this way, women posed a threat to the prison guards, ensured that inmates were accounted for (most of the time), and within a system designed to monitor and dehumanize prisoners, the women sustained a counter-culture of scrutiny and compassion to keep a (temporary) check on prison corruption.

According to the Naxal women, surveillance (chokh rakha or keeping an eye) was the supreme right of state officials managing prisons, but women developed their own informal surveillance teams and practices which mocked the state. It was the task of the state to spy on the inmates in order to control them; however, women prisoners, who were cheated by the state, used the same methods to protect the prison population. Over time, women's performances integrated into their prison routines. Through circulating dramatically divergent life stories; mixing songs across class, caste, and rural-urban divides; sharing coarse jokes; learning anecdotes about how to fool the guards; through performing secrecy (ishara or conveying messages without words), the long-term convicts and new political prisoners created an inner world of inmates and undertrials with unique rules, culture, music, and language. These instances of performing joy and roleplaying were not dissimilar to the experiences of political prisoners during the colonial period. For example, the romanticism associated with colonial prisons in Calcutta are contained in an emotional timewarp, since they once housed iconic revolutionary leaders such as Aurobindo and Netaji Subhas Chandra Bose. Several political prisoners, who survived years of persecution while the colonial state tried to implicate them in a number of sedition cases, later wrote about the secret social life of prisons. In his autobiography, writer and former revolutionary Shibram Chakraborty poignantly described his engagement with political activists and rebel poets in detention; the interior world of prison life was introduced to Chakraborty as 'ekhon amader gaan abritti hoi holla koto ki hobe-now we will have songs, poetry recitals, shouting and fun, so much is about to happen'. ${ }^{41}$ The women prisoners also aggravated the guards as these kinds of noisy performances were forms of resistance to the violent muting practices developed by local state actors. They denied the alienating detention system access to the freedom and practices of the inmates' intimate universe which was governed by a micro-culture of subsistence and resistance.

\footnotetext{
${ }^{41}$ S. Chakraborty (200o), Ishwar Prithibi Bhalobasha (God, the World, Love), Nobopotro Prokashon, Kolkata, p. $3^{84}$.
} 
A number of former Naxal women also remembered the performance of familial relationships in prison, which weathered the guards' attempts to isolate inmates from affective bonds. For most stigmatized convicts, families were lost in the world outside prison. Parents were both concerned and embarrassed to have incarcerated daughters. Due to the legal complexities and the culture of suspicion generated by the strength of the Naxal movement, families were often denied any visitation rights and inmates could not rely on a kin network beyond the remits of the prison. A body of research on revolutionary marriages shows how in most instances political women had walked away from conventional family set-ups to marry fellow comrades or be their mistresses. ${ }^{42}$ Faith in the Maoist ideology had generated a radical understanding of political love and established an appreciation of alternative moral economies among young Naxals. Many political women were widowed when they entered the prison system, often having witnessed the violent death of their revolutionary husbands. In my personal interactions with a former Naxal leader, she reminisced at length about her unsympathetic husband who quickly remarried while she was serving her sentence. Whether stemming from 'radical love' at a particular juncture in urban history, or as compensation for the breakdown of familial relationships, the political women in prison lovingly remembered playing 'happy families' and how the inmates developed sisterly and maternal relationships and called each other ma or bon or didi.

Many Naxalites confessed that convict inmates developed affectionate relationships for long periods of time, and Naxal women were drawn to these enactments as they served as a primary coping mechanism in prison. According to Roy, when young Naxal men and women desired a utopian world, the idiom of 'love' found new usage. The author states: 'The imagery of love fused new aspirations and passions for revolutionary violence, subverting its erstwhile "bourgeois" underpinnings. Love was (re)imagined as a form of comradeship that transpired only in the revolutionary cause. ${ }^{43}$ However, Roy's interviews with former male and female revolutionaries show that even within the revolutionary community, women's exhibition of autonomous love was controversial and contested. 'Living together', romancing a married man, and marrying

\footnotetext{
${ }^{42}$ S. Roy (2006), 'Revolutionary Marriage: On the Politics of Sexual Stories in Naxalbari', Feminist Review, vol. 83, no. 1, pp. 99-118.

${ }^{43}$ Ibid., p. 100.
} 
by the Red Book were overtly associated with sexual licentiousness and indecency. ${ }^{44}$ While many women positively associated love and freedom of association with individual choice, the overriding ideology within the movement was that of dependent femininity and heroic masculinity. ${ }^{45}$ My research suggests that the prison space offered Naxal women an opportunity to express and experiment with (potentially asexual) 'love' without being scrutinized and morally reprimanded by male comrades in the movement. Yet the everyday expression of that love (sometimes criticized by guards and inmates) inadvertently retained its revolutionary imagination, primarily as a resistance against unjust authority. For example, Joyeeta (6o), imprisoned for four years in her twenties for her political activism, remembers being comforted, washed, and fed by her convict prison 'mother', especially after prolonged beatings organized by the warden. She said: 'Like in a mother-daughter relationship, when Ma asked me about the bruises I would say I had fallen down the stairs to protect her from the emotional humiliation of seeing her daughter in pain and beaten up by men. We both knew the truth. But we still invested in performing these relationships to give a human face to a loveless prison space.' In her memoirs, Mitra mentions her encounter with Phulmala, jailed for life after she had killed her two children. She was married off at 14 and became the second wife of a sharecropper. After years of domestic violence and starvation, she snapped. In a fit of rage she poisoned her children and slit her own throat with a sickle. A villager found her dying in the field and decided to save her. 'Phulmala? Someone whose arms are never empty?' wondered Mitra after hearing her story. 'Even the filthiest child in the ward finds a place in them. She is always carrying a baby on her hips,' she wrote. ${ }^{46}$

While the prison staff mocked instances of surrogate motherhood and sisterhood, they had strict rules against same-sex love. Going against the 'two-women-per-cell' prison policy, there were at least three women huddled in a small cell at night to prohibit the pursuit of pleasure between women lovers. Even though most Naxal women refrained from narrating episodes of same-sex love-if there was a policy of deterrence, there may have been occurrences-they did mention controversial affective ties in prison. Kanaka (6o), a political

\footnotetext{
${ }^{44}$ Naxal couples married using Chairman Mao Zedong's 'Little Red Book' of quotations as a sacred text.

${ }^{45}$ Ibid., p. 107.

${ }^{46}$ Mitra, Killing Days, pp. 22-23.
} 
prisoner whose lover was shot dead during a police siege, said her life in prison was made tolerable by her close friendship with a refugee boy. During the Bangladesh Liberation War in 1971, a number of fleeing Muslim families were captured at the India-East Pakistan border and imprisoned in Alipore Central Jail. Kanaka was approached by a young Muslim boy and she chose to become his wife (bibi). She performed a loving marital relationship with the young boy, Mishu. Accused of being perverse by the guards and irreligious by the Hindu convicts, Kanaka insisted that it was a meaningful attachment in which the boy looked after her, got her food, passed on prison gossip, and protected her like a good husband. 'Our love play was not about age, religion and sexual duties. There was none of that. We were both just desperate for love and companionship in prison. Even in regular adult marriages, women move between being mothers, sisters and friends to their husbands. That was the crux of my profound relationship with Mishu. It's not twisted. I don't expect anyone to understand that,' she said. In this case, the heroic masculinity of a young boy, and the play of dependent femininity by a young female revolutionary, was represented as a form of enduring and rebellious love by Kanaka. When the boy was eventually released, Kanaka was forlorn. When she was granted amnesty, she travelled in vain to Pakistan in search of the boy and to this day, the sexagenarian remembers the warmth of her feelings for her 'prison husband'. In the end, the prison space recollected by the Naxal women as their 'exceptional past' was an alternative space for non-normative relationships, yet they emerged through the repeated performance of normative familial ties. These women had rejected kinship to join an anti-state movement. Before their capture, political mobilization was their resistance against a patriarchal state determined to keep women within the family. When in prison, and with the state so keen to separate women from their families, the women recreated and sought comfort in artificial family units to retain continuity with their anti-state resistance. The practice of carrying out fictive relationships and, at times, impermissible role-playing, allowed Naxal women to display their vulnerability and momentarily shed their tough exterior as hardened political insurgents. ${ }^{47}$

\footnotetext{
${ }^{47}$ For more details on the aesthetics of prison life, see A. Sen (2015), 'Slaps, Adda, Beatings and Laughter: The Performance of Joy and Political Aesthetics in a Women's Correctional Facility in Urban India', in R. Kaur and P. Mukherjee (eds), Arts and Aesthetics in a Globalising World, Berg Publications, Oxford.
} 
There were various limits to women's solidarity. The inmates had jealous arguments and hierarchies; they snitched on cellmates; stole, and siphoned off resources; developed kind relationships with the guards for periods of time, and, at others, received a massive thrashing if they became rebellious. Jamini (70), a former political prisoner, reminisced about her cellmate Sheila who was a renowned local prostitute. Sheila's court hearing was due, and she was terribly upset to hear about her potential prison sentence. During conversations with Sheila, Jamini discovered that the judge overseeing her court case, a married and celebrity socialite in Calcutta, was a regular client. Through enacting hilarious caricatures of the judge, ridiculing him, and jeering at his secret sexual fantasies (involving frills and ribbons), Jamini used humour to demystify class and sexual hierarchies for Sheila and persuaded her to challenge the judge in court. When a defiant Sheila was dragged into the witness box, she pointed her finger at the judge and shouted 'tui roj amar bari ashish, tui kon adhokare amake shashon korchish? You come to my house every day, who gives you the right to judge me?' She was promptly released with a small fine. Sheila returned to prison to thank Jamini for saving her from prison life and empowering her in the real world, and she gave some of her old clothes to Jamini as a gift, which she politely took. The next day, she burned them in the prison yard as she was scared that her low immunity, due to illness, starvation, and open wounds from torture, would make her vulnerable to contracting a disease from the prostitute's soiled clothes. Other inmates taunted Jamini for this act, accusing her of openly rejecting her high ideals. Her actions drove a momentary wedge in the solidarity among the inmates, but also made Jamini disillusioned about her own political ideology, which was once committed to offering dignity to the bodies of the poor.

Many Naxal women, however, remained nostalgic about the ways in which their encounters in incarceration enabled them to wander beyond grand ideology, and engage with quotidian structures of perseverance, challenge the everyday normalization of violence against women, and have a collective impact on the dynamics of survivalism in prison. While torture and prison ideologies are directed towards confusing inmates about structures of time, place, and emotions, that loss of contact with reality can also facilitate confessions. The narratives in this article show how various groups of prisoners strove to reconstitute relationships and structures of time and place by creating their own internal universe of social and political liaisons. 
After their release, many of my informants were gently (or not so gently) persuaded to be married off. Some women resisted coercion and eventually married former male revolutionaries who shared their anti-state rhetoric. Some of them never married. Many of them became activists, teachers, social workers, and took up other roles with community responsibilities 'in order to keep a link with the past', as Mita said. Some others left their homes after facing further stigma within the family for serving prison sentences and tried to start life afresh in unknown cities.

Sumitra (68), one of my interlocutors, remembered a summer afternoon seven years after her release from prison when she was hurriedly crossing a busy street. She saw a prison official, who had repeatedly slapped her face until he broke her jaw, on the other side of the road. She urinated in her sari, but apparently managed to just walk on. Another former political prisoner, Sheema (70), cannot sleep if she hears a police siren during the night, but she insisted that she had not and would not have 'a mental breakdown'. There are many women revolutionaries who are still fighting official court cases against prison authorities. Some of them have severe disabilities resulting from torture. ${ }^{48}$

Alpa Shah, in her ethnography of electoral practices in rural Jharkhand, proposes that a study of everyday social relations which give rise to imaginings of the state can enable us to understand the way in which state-society relationships come to exist on the ground. Shah's analysis shows how Munda communities cast their vote and participate in democratic processes in order to 'keep the state away'. ${ }^{49}$ The Naxal women's imagining of the state also varied in the context of the struggle and later in prison; however, their engagement with the state and their imagining of it, through the kaleidoscope of ideology, violent uprising, everyday negotiations within the confines of prison life, as well as in their post-prison life trajectories, were mostly directed towards 'keeping the state away'. Importantly, several of the Naxal women I interviewed, sustained an idea of the hybrid and subjective relations experienced in prison as freedom, as opposed to the oppressive and predictable power relations that exist in mainstream society.

\footnotetext{
${ }^{48} \mathrm{http} / /$ indiatoday.intoday.in/story/former-calcutta-police-assistant-commissioner -sentenced-to-one-year-imprisonment/1/283707.html, [accessed 5 March 2018].

${ }^{49}$ A. Shah (2007), 'Keeping the State Away: Democracy, Politics, and the State in India's Jharkhand', Journal of the Royal Anthropological Institute, vol. 13, no. 1, pp. 129-145.
} 
Mita ended her prison narrative by talking about her life after she was discharged. She was married off without any delay and her family had to pay a big dowry to cover up her past. Her husband, who taunted her as 'the once jailed daughter-in-law (jail khata barir bou)', forced her into domesticity, motherhood, and sexual obligations. Her parental family also compelled her to complete her education and graduate to make amends for her aberrant past, and eventually she found that she had submitted to the same social and educational system that she had once battled against. She repeatedly said that her performance of laughter and family-making in prison (shukher natok) gave her deep satisfaction, despite all the beatings. She said: 'Superficial performance of happiness in real life, of normative wifehood and motherhood, such as packing tiffin boxes for my grandchildren and giving my husband his wallet when he goes out, they leave me dry and bereft.'

\section{Conclusion}

This article examines how informal performances in incarceration, not recognized by the state as standard prison policy, created temporary resistant cultures of confinement at a critical juncture in the history of eastern India. I show how local actors affiliated with prison governance-guards, wardens and their accomplicesoften used excessive and extra-legal means to exert control over political seditionists, and I underline the vitality of occasional, collaborative challenges offered by women political prisoners to that authoritative administration. The performances, which mocked and resisted the state, in turn set limitations to the de facto sovereign practices generated by state officials within prison systems. Local representatives of state sovereignty expressed their power not only through the use of brute force on inmates, but also through distancing women inmates from experiences of community comfort and solidarity. The article shows how anti-state prison publics (led by a group of female Maoist revolutionaries and supported by a criminalized population) used improvised and indigenous forms of surveillance, resistance, and feminine rituals to resist localized and everyday expressions of state supremacy.

This article has shown how state representatives, who constitute the quotidian and (at times) humane face of the state's sovereignty practices, can attempt to establish extreme authority in 
state-sanctioned, legal spaces. ${ }^{50}$ Through an analysis of (a fragment) of carceral politics in Alipore Central Jail in the 1970s, I have argued that this spectacle of ruthless state power is fragile and inequitable, and that both prisoners and prison officials use sublime violence, with unpredictability and incalculable potency hidden in its multiple unforeseen strategies, ${ }^{51}$ to establish dominance over each other. In the context of my research, I discovered that women prison guards acted as agents of the state, but positioned their authority between caste, class, and gendered construction of ideal womanhood. Women with guns who served the state claimed to have legitimate power over women with guns who were against the state, even if the latter came with caste and class privileges. The women revolutionaries were aggressive militants themselves and were well aware of women's capacity for violence, yet their claim to moral superiority lay in condemning women who sided with the state and not with other defenceless, persecuted women. This article thus highlights how a prison population used limited material, ethical, and affective resources, including music, laughter, and puppet shows, to set limits to the state's desire for punitive control. I unravel how such performances served as entertainment and tactics for countersurveillance, and emphasize the role of indiscipline and disobedience as a form of symbolic violence against the public authority of the state (as against the direct violence of prison riots).

Satadru Sen, who studied the politics of female imprisonment in colonial India, argues that the discourses of social rescue, moral reform, and racial-political authority usually converged in the punishment of women. ${ }^{52}$ Hence lapses in the practice of this punishment made British observers nervous. Sen states: 'When women prisoners mingled indiscriminately, defecated in public, quarreled, escaped, died, or fought with jailors over control of their children, they did not simply "resist". They undermined a prestige and a confidence that were inextricable from the spectacle of colonialism ... As failure reinforced failure, the female wards became not so much reminders of the success of colonial punishment, as embarrassing signposts of an

${ }^{50}$ A. Mbembe (2003), 'Necropolitics', Public Culture, vol. 15, no. 1, pp. 11-40.

${ }^{51}$ Bart Klem and Sidharthan Maunaguru, 'Public Authority Under Sovereign Encroachment: Leadership in Two Villages During Sri Lanka's War' in this special issue.

${ }^{52}$ S. Sen (2002), 'The Female Jails of Colonial India', The Indian Economic and Social History Review, vol. 39, no. 4, pp. 417-438. 
abandoned mission. ${ }^{53}$ This embarrassment remained fundamental to the governance the Naxal prisoners: their attempts to challenge divisive practices in prison also underlined the failure of the postcolonial state to keep control over its citizenry and its institutions. According to Sen, these failures matter not only because they indicate the difficulties of developing modern penal regimes, but also because they represent a perceptible anxiety about the historical failures of public institutions acting as shadow states. ${ }^{54}$

While the idea of incarceration remains abstract in public discourse, political imprisonment can act as a powerful critique of civil rights violations and the concomitant legitimacy of the state in India. This article eventually argues that cultures of state regimentation in South Asia are sustained through socio-political negotiation between state actors and their supposedly muzzled subjects. Though designed for extreme state domination, the presence of young women political insurgents in a subaltern prison world could potentially skew power relationships between the torturer and the tortured, the prison officials and the inmates, the state and the citizens. The prison space, where the state aspires to exercise unchallenged supremacy, especially over a dangerous population that has been removed from mainstream freedoms, can become a site for small, embodied, gendered wars over physical, social, and political sovereignty. Despite limitations to solidarity among inmates, the simple acts of recreating familial and kinship networks, and the nurturing of an independent universe of inmates, with its own prompts, rules, and responses to critical events, creates a debate about the weaknesses of state sovereignty within ceaselessly growing carceral worlds in the region.

${ }^{53}$ Ibid., p. $43^{8}$.

${ }^{54}$ Ibid., p. 421. 